\title{
The Economic Improvement of Farmers in Sei Mencirim Through Independent Cassava Chips Industry
}

Fajar Utama Ritonga, Hairani Siregar

Faculty of Social and Political Science, University of Sumatera Utara

Email: Fajar1utama5@gmail.com

\begin{abstract}
Abundant agricultural products did not necessarily provide anincreased economic income of the farmers in Sei Mencirim Village, District of Sunggal, Deli Serdang. It is caused by low selling prices of agricultural products in the market, one of which is the result of cassava farming. The farmers have tried some innovation to increase the income of their household economy by creating an independent industrial cassava chips. However, in practice, the group is constrained by the lack of innovation of the products so that the products can not compete with the similar products on the market. Besides, independent industries are also not professionally managed. This then implements an independent industry did not go well.The program aims to improve the local economy through standalone independent industry of chips cassava, so creating enterpeurnership skill for each member who participated in each the training, increasing Sei Mencirim farmers' collectivity, stimulating their ability to see all forms of business opportunities through the use of natural resources in the surrounding areas, improving the ability to be in innovative and marketable processing ofcassava chips, therefore increasing their income.The results obtained through these activities is that it increases collectivity in Sei Mencirim farmers, their spirit of entrepreneurship and their ability to see business opportunities that exist around them.
\end{abstract}

Keywords: Farmers Group, Independent Industry, enterpeurnership

\section{PRELIMINARY}

Sei Mencirim, District Sunggal Deli Serdang is a rural area that borders the city of Medan. Although directly adjacent to the city of Medan, most people Sei Mencirim still maintain their livelihood as farmers. Looking at the data owned by Sei Mencirim 2016 looks as much as sixty percent of the population are subsistence farmers. Various agricultural products Sei Mencirim they are sweet.

During this time the plant yam regarded as easily planted by residents Sei Mencirim for fertilizer and water consumption is not too much. Also, sweet cassavais also considered treatment plants do not need the extra time. It can benefit some farmers where they can search for additional income outside their main job as a cassava farmer.

Although it does not require extra time and costs in maintenance turns out planting cassava also provide various dilemmas to farmers Sei Mencirim. Farmers feel that the selling price of cassava until recently was not as reliable as fulfilling family life. Just imagine for one kilogram of cassava until now only touched the highest price of Rp. 700.00 per kilogram.
In 2014 a group of farmers Sei Mencirim never tried to breakthrough to create industrial centers that cassava chips around village. These operations will only last two months due to various factors. The independent industry run by housewife who want to fill their free time with activities that can increase their household income. have not had time to develop, the independent industry must be willing to compete with a variety of processed cassava chips that modern processing and packaging. Lack of capital owned by the group also provides its problems. Cassava chips industry Sei Mencirim difficult to expand the market.

Innovation is also minimal carried out during the production of chips takes place. During this time a group of farmers just fry chips and then packaged in plastic without any difference with cassava chips are sold in general regarding both taste and packaging. This then makes chips production farmer groups Sei Mencirim difficult to be accepted in the market.

Seeing the selling price should parsnip cassava chips business in sei Mencirim can create a business opportunity that is promising. Aside from simple raw materials in the can, a tree planting cassava Sei Mencirim also not fixated on a 
particular growing season like other crops, which means every time the raw material cassava is always available at Sei Mencirim.

Improve the local economy through socioeconomic empowerment should be encouraged oriented resource utilization around. By utilizing social resources and the natural resources that exist will generate strong communities both socially and economically. Therefore, through the innovative production of cassavachips, Sei Mencirim will be farmers not only sell their harvest results to the industry as raw material but can also be processed as an innovative product that can provide economic benefits for farmers themselves.

During this time cassava crops SeiMencirim Village residents, District Sunggal, Deli Serdang district relies only on industry sales alone. Not infrequently the price they receive is also sometimes difficult to meet their basic needs. Independent industry, cassava chips previously they manage actually can potentially increase the economic income. However, from the results of preliminary observations found some problems faced by the groups in this Mencirim Sei.

Some of the problems faced by farmers, among others, the lack of innovation of flavors of chips processed result them, seficciency owned equipment to perform processing, and less well marketing process carried out by farmers. Also, the problems faced is the unclear structure organisms farmer groups Sei Mencirim which causes overlapping of responsibilities in the execution of their duties and responsibilities.

\section{METHOD OF EXECUTION}

The whole series of service activities include several stages of implementation that begin with mapping the potential possessed by farmer groups Sei Mencirim. Sei Mencirim has very good land for the production of cassava plants, in addition to the resident Sei Mencirim also has potential in the processing of cassava chips, so it can be concluded the potential of village communities is very large Mencirim Sei-related processing of cassava. It is then worth noting is the lack innovating and equipment owned to support all production activities.

On occasion, the team visits to farmer group Sei Mencirim on 20 July 2017. The team was able to meet Mr. Heru as the coordinator of a group of farmers. Mr. Heru welcomed the community service program will be held. Mr. Heru again invited a team of dedication on July 23,2017 , to directly describe His form and activities of interest to all members of the farmer groups. The day was also signed agreements of cooperation agreements between the teams dedication and farmer groups Sei Mencirim. The meeting also agreed on farmer group representatives who will participate participated in community service. Lina's mother, Mrs. Nur, Madliati mother, and the mother Suratmi be representatives of farmer groups as participants devotion.

After obtaining sufficient data and understanding related to the potential and problems experienced by farmers and communities Sei Mencirim, conclusions do perform service activities with the economic improvement of farmer groups through cassava chips industry. The basic thing that needs to be done of course preparation material supplied to the farmer groups linked to the organization's management of marketing materials, these two things are considered the most important requirement to be applied by the farmer groups Sei Mencirim considering the problems that they faced before. By understanding the management aspects of the organization is expected farmers to run their group collectively and have the right goal and the same.

This activity starts on August 3, 2017, held at the Secretariat of Farmers Group Sei Mencirim. In this activity socialization phase of the program devoted to the representatives of farmer groups in the dedication program. In this activity, the participants were very enthusiastic in welcoming the implementation of the program. This is evident from the various questions and various ideas they convey.

This stage is also an event determining the location of cassava chips production. After a fairlylong discussion then Ibu Lina became independent production locations cassava chips. Ibu Lina rated closer to the access road that will ease the distribution of raw materials and production.

Tim devotion realizes that Tani Sei Mencirim not previously been doing a production business that is professional. Then the devotion teams provide a variety of materials related to entrepreneurship such as the operational management and marketing of industrial products, small business management, market share and strategy development to increase income is also a priority. This extension is expected to create the 
effectiveness of performance to achieve a competitive advantage with lower costs and better services delivered by a team of experts from the economic department of accounting. Counseling about marketing strategies, concludes with a discussion to agree on a marketing strategy to accelerate business unit marketing both online and offline.

In addition to the formation of work teams, to produce a professional business unit and has the goal of sustainable it is necessary to set up the finance team. Thus the team felt it was important to facilitate the formation of the working group of the financial system to work professional fore. The key points are produced such as the determination of the amount of profit sharing and a regular schedule to be performed by the groups. Coordinator and responsible will get $23 \%$ of the total profit, while $5 \%$ of the profit will be allocated as cash. Profit sharing will be done every two weeks to the members of the team.

The next stage is to provide training to farmers and community groups related activities industry production of cassava chips. To support this stage, community groups are given training and counseling involving one of the instigators of cassava chips industry in Medan, Ms. Syarifah Nadira which is the second partner in these service activities. It is emphasized in this training are allow community groups can deliver innovation and results related to the sense of processed cassava chips are made.After discussion, it was agreed aschedule of training is done every Monday, Thursday, Saturday, and Sunday at $13.00 \mathrm{pm}$.

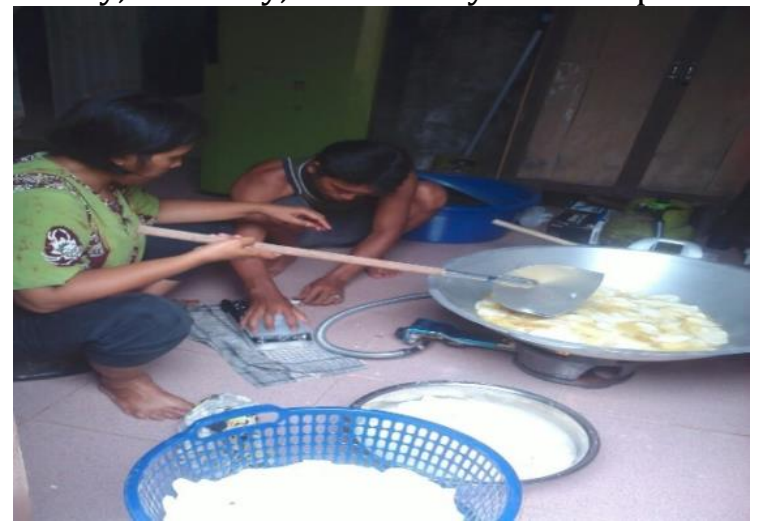

Cassava raw materials used in these activities is a type of yam flour. Results fried cassava is considered crisper than on other types of sweet cassava in the village of Sei Mencirim. Also, many farmers who grow cassava flours compared to other types of cassava because of this kind are sought after by the public as the basic ingredients of theprocessed food. Yam yam used is less than one year old. Yam age selection aims to minimize the results of kerupuk hard after frying.

In the production process, there are some things that need to be considered to maintain the quality of production. The cutting process greatlyaffects the sweet texturecassava after frying later. If too thick cut cassava fried cassava, then the results will have a harder texture. For cassava bread, cutting thickness ranges from 1-2 mm. After the cut cassava, sweet cassavacan notbe left too long. If left too long, cassava would easily bend when fried cassava chips that form no longer attractive shape. Which becomes the most attention is iving taste after sweet fried and drained. Flavorings are used in the form of seasoning to taste cheese, roast beef, and corn, following a favorite snack taste both adults and children.

To increase consumer appeal of the results of an independent production of cassava chips packing systems using plastic press machines. Also, to beautify the appearance of cassava chips packaging, this press machines will also ensure airtight packaging cassava chips, so the cassava chips in it will be more durable.

After all the training activities, farmer groups Sei Mencirim started doing aproduction of cassava chips. Based on the results of monitoring carried out, the farmers began to be able to process cassava well, especially cassava produced in Sei Mencirim the yams with excellent quality.

\section{RESULTS AND DISCUSSION}

During this time the residentscassava crops Sei Mencirim, District Sunggal, Deli Serdang district relies only on industry sales alone. Not infrequently the price they receive is also sometimes difficult to meet their basic needs. Independent industry, cassava chips previously they manage actually can potentially increase the economic income. With the dedication activities, farmers can make cassava processing independently and be able to sell their cassava processed at a decent price and cover production costs.

A group of farmers in the village of Sei Mencirim now have an understanding of management related to their organization, so that the entire process can be do properly and regularly, as well as the disappearance of the culture of overlapping responsibilities and tasks 
owned by members of farmer groups. Seeing the development of farmers are happy with the changes experienced in their organizations.

Through these activities create many jobs that can improve the welfare of people in the village and surrounding Mencirim Sei. Farmers who grow cassava begin to reduce the interest slowly returned to farming; this is because during this yam are the mainstay of farmers in the village of Sei Mencirim. Through this activity, farmers no longer feel the loss because they have to sell cassava at a very low price.

After receiving training in the activities related to marketing, farmers no longer rely solely on word of mouth for their produce. It also bring up new jobs for young people who want to help market their products. The marketing activities are focused to put items in stores that are around Sei Mencirim. For the next stage of marketing is done in several media, including social media.

To give a sense of security and comfort to consumers who will buy cassava chips product Sei Mencirim farmers, they began to perform several steps related to certification, whether certified kosher certification as wel of National Agency of Drug and Food Control. With a complete whole product certification, the expansion will continue to be done by starting to enter a product into a minimarket.

\section{CONCLUSION}

Community service activities in the form of an independent production of cassava chips in Sei Mencirim conducted Institute for Research, and Community Service (LPPM) Field Service received a very good response from the target program. It can be seen from the enthusiasm of farmer groups to follow each stage of devotion. The results of the process of this devotion have been able to form a working team independent production of cassava chips. The team started working with the agreed rules, together with the dedication as a facilitator in it. The result of the training has helped the team cassava chips production work independently in making cassava chips in a decent packaging sold in the market

This service activity managed to restore the spirit of cassava farmers in the village of Sei Mencirim in planting. Increasing farmers' income perceived enterperunership successfully cultivate the spirit within them. The structure and form of organization farmer groups Sei Mencirim now clear and well organized. New jobs are emerging with increasing cassava chips industry which was developed by the farmers Sei Mencirim.

\section{BIBLIOGRAPHY}

Burgon \& Huffner. 2002. Human Communication. London: Sage Publication

Cathart, R.S., and Larry A. Samovar, 1974. Small Group Communication: A Reader. New York: Holt, Rinehart and Winston, Inc.

Chamala, R.S., 1995. Overview of Participative Action Approaches in Australian Land and Water Management. Dalam Chamala, S. and Keith, K. (eds), 1995.Participative Approaches for Landcare: Perspective, Policies, Program. Brisbane: Australian Academic Press.

Chambers, R. (1985). Rural development: putting the last first. London; New York: Longman.

Effendi, Onong Uchjana 2003. Ilmu Komunikasi Teori dan Praktek. Bandung: PT. Remaja Rosdakarya.

Hikmat, H., 2004. Strategi Pemberdayaan Masyarakat. Penerbit Humoniora, Bandung.

Kartasasmita, Ginandjar, 1996. Pembangunan Untuk Rakyat- Memadukan Pertumbuhan dan Pemerataan. Penerbit PT. Pustaka CIDESINDO, Jakarta.

Khairuddin, 2000. Pembangunan Masyarakat., Tinjauan Aspek: Sosiologi, Ekonomi dan Perencanaan. Liberty, Yogyakarta.

Ife, J.W., 1995. Community Development: Creating Community Alternatives-vision, Analysiis, and Practice. Melbourne: Longman.

Prijono, O.S. dan Pranarka, A.M.W., 1996. Pemberdayaan: Konsep, Kebijakan dan Implementasi. Centre for Strategic and International Studies, Jakarta.

Sumodiningrat, G. (1999). Pemberdayaan Masyarakat dan Jaring Pengaman Sosial Jakarta: Gramedia.

Syahyuti, 2006. 30 Konsep Penting dalam Pembangunan Pedesaan dan Pertanian. Jakarta : Bina Rena Pariwara.

West, Richard \& Lynn H. Turner. 2009. Pengantar Teori Komunikasi: Analisis dan Apilkasi. Jakarta: Salemba Humanika. 